\title{
Hirtelen szívhalál rizikóstratifikáció aritmogén jobb kamrai cardiomyopathiában
}

\author{
Clemens Marcell
}

Debreceni Egyetem, Klinikai Központ, Kardiológiai és Szívsebészeti Klinika, Debrecen

Levelezési cím: Dr. Clemens Marcell

Debreceni Egyetem, Klinikai Központ, Kardiológiai és Szívsebészeti Klinika, 4032 Debrecen, Móricz Zsigmond krt. 22.

E-mail: marcellclemens@gmail.com

Az aritmogén jobb kamrai cardiomyopathia (ARVC) egy örökletes betegség, amelynek hátterében elsősorban desmosomális proteinek mutációja áll. Klinikailag kamrai ritmuszavarok, majd későbbi stádiumban szívelégtelenség kialakulása jellemzi, de első tünete a hirtelen szívhalál is lehet. Az elmúlt években számos rizikófaktort azonosítottak, amelyek segíthetnek a hirtelen szivhalál rizikójának becslésében. Ezen rizikófaktorok összesitése, súlyozása alapján született meg 2015-ben egy nemzetközi állásfoglalás, amely ajánlásokat is megfogalmaz az ICD indikációját illetően. Ennek alapján ICD-implantáció javasolt ARVC-ben szekunder prevenciós céllal, illetve profilaktikusan súlyosan csökkent jobb és/vagy balkamra-funkció esetén (I. osztályú ajánlás) és legalább egy major rizikófaktor (syncope, nem tartós kamrai tachycardia, közepes fokban csökkent bal és/vagy jobbkamra-funkció) esetén (Ila osztályú ajánlás).

Kulcsszavak: aritmogén jobb kamrai cardiomyopathia, hirtelen szívhalál, implantálható cardioverter defibrillátor

\section{Sudden cardiac death risk stratification in arrhythmogenic right ventricular cardiomyopathy}

Arrhythmogenic right ventricular cardiomyopathy is an inherited disease predominantly with the mutation of desmosomal proteins. Clinically the presence of ventricular arrhythmias and in late stages heart failure is characteristic; however, sudden cardiac death could also be the first manifestation of the disease. Recently several risk factors of sudden cardiac death was identified. Based on the systematic review of these risk factors an international consensus statement (2015) was published also with recommendations on the indication of implantable cardioverter defibrillator (ICD) implantation. According to the document an ICD as a secondary prevention and prophylactically in patients with a severely depressed left and/or right ventricular function (class I.) and also for patients with at least one major risk factor (syncope, non-sustained ventricular tachycardia, moderately depressed left and/or right ventricular function), (class lla).

Keywords: arrhythmogenic right ventricular cardiomyopathy, sudden cardiac death, implantable cardioverter defibrillator

$\mathrm{Az}$ aritmogén jobb kamrai cardiomyopathia (ARVC) egy genetikus, elsősorban a desmosomális proteineket kódoló gének mutációján alapuló betegség, ami klinikailag a kamrai myocyták közötti fizikai kapcsolatok megszakadásával, a sejtek közötti jelátviteli utak károsodásával és következményesen sejtelhalással, az érintett myocardium régió zsíros-kötőszövetes elfajulásával jár. A betegség klasszikus formájában döntően a jobb kamra érintettsége a jellemző, de egyes variánsok a két kamra hasonló vagy elsősorban a bal kamra érintettségével járnak. Genetikai vizsgálattal az ARVC-s esetek kb. 50\%-ában lehet kóroki mutációt igazolni. Leggyakrabban a plakophilin-2 (PKP2) génmutáció fordul elő (az esetek kb. 10-45\%-áért felelős), amelyet a desmoplakin (DSP: 10-15\%), desmoglein-2 (DSG": 7-10\%), és a desmocollin-2 (DSC2: 2\%) mutációi követnek (1). Diagnózisához a 2010-ben publikált módosított kritériumrendszer nyújt segítséget, ahol a képalkotó vizsgálatok (echo/MR), szövettani eredmények, nyugalmi és ritmuszavar alatti EKG-eltérések, 


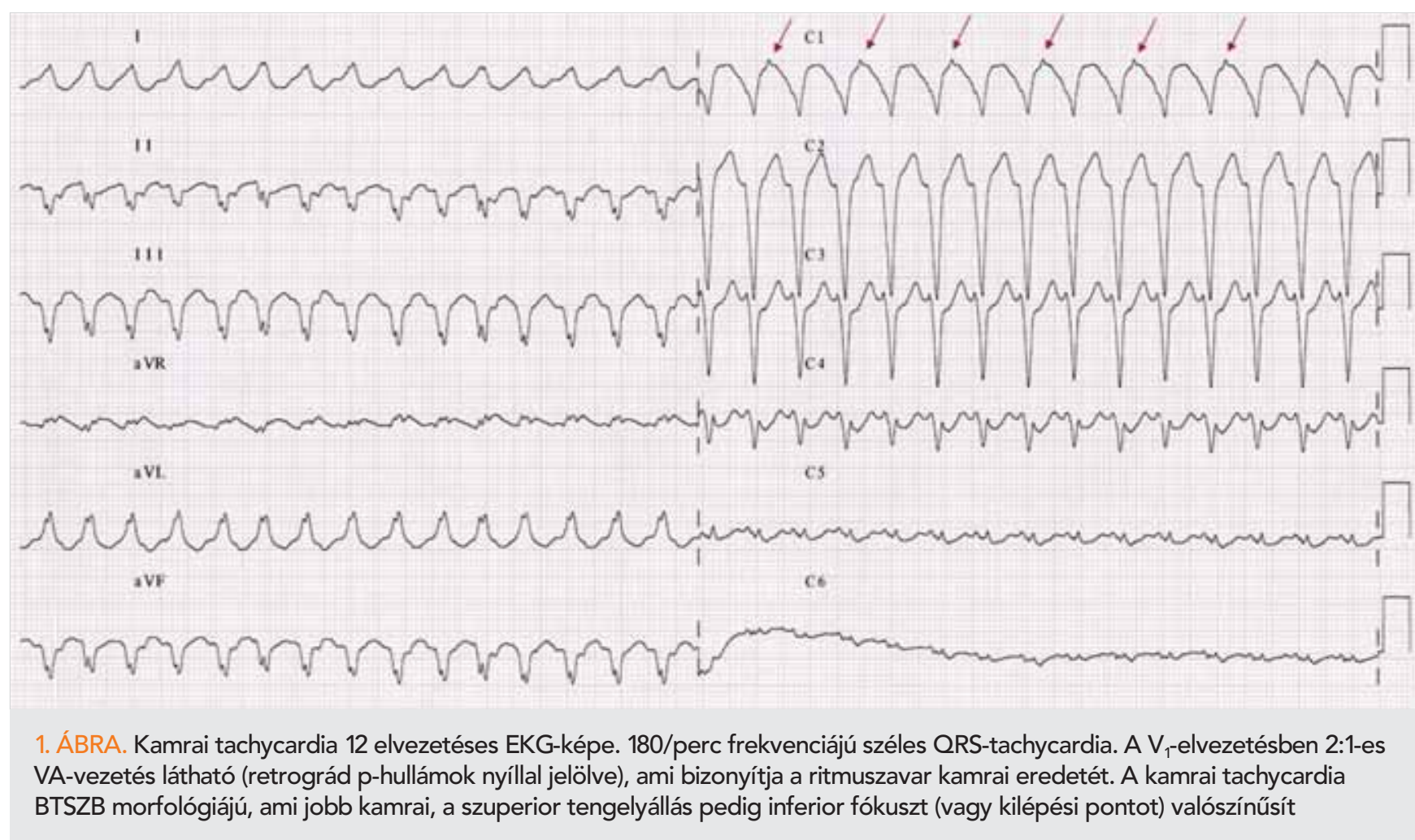

illetve családi anamnesztikus adatok alapján állítható fel a diagnózis (2). Fontos azonban megemlíteni, hogy a fenti kritériumok elsősorban a klasszikus, dominálóan jobb kamrai érintettséggel járó ARVC diagnózisára alkalmasak, azonban a döntően a bal kamrát érintő formák azonosításában csökken a szenzitivitásuk (3).

A betegség klinikumát tekintve elsősorban kamrai ritmuszavarok: kamrai extrasystolék, nem tartós és tartós kamrai tachycardiák (1. ábra) jellemzik; a szívelégtelenség tünetei csak későbbi stádiumban jellemzők. A tartós kamrai ritmuszavarok hirtelen szívhalált is okozhatnak, ami akár a betegség első tünete is lehet. A hirtelen szívhalál megelőzésére egyértelmüen bizonyított, hatékony gyógyszeres lehetőség nem áll rendelkezésre, bár a béta-blokkolók adása - kontrindikáció hiányában - rutinszerüen javasolt minden diagnosztizált beteg esetében. A prevenció egyetlen hatékony módja más cardiomyopathiákhoz hasonlóan a primer vagy szekunder céllal beültetett implantálható cardioverter defibrillátor (ICD). Az ICD-terápia potenciálisan életmentő jellege mellett már középtávon is jelentős szövődmények jelentkezhetnek, külön kiemelve egy esetleges indokolt vagy indokolatlan sokk leadás életminőségre gyakorolt negatív hatását. Másfelől az ARVC jellemzően fiatalkorban diagnosztizált megbetegedés, a betegek diagnóziskori átlagos életkora: 32 év és emiatt ezen betegek a hirtelen szívhalál hatékony prevenciója esetén várhatóan hosszú ideig élnek, hosszabban lesznek kitéve a terápia potenciális mellékhatásainak is. Éppen ezek miatt kritikus döntés egy ARVC-s beteg esetében, hogy mikor kerüljön sor az ICD implantációjára. Koráb- bi vizsgálatok alapján lényegesen magasabbnak tủnt az ARVC-s betegek HSZH rizikója, amit elsősorban az magyaráz, hogy ezek az adatok olyan tercier centrumokból származtak, amelyek elsősorban a súlyosabb betegeket kezelték. Újabb vizsgálatok alapján az átlagos éves HSZH-rizikó 1\% körül lehet (4).

Utóbbi évek eredményei alapján egyre inkább úgy tűnik, hogy a tartós kamrai ritmuszavarok, hirtelen szívhalál megjelenése manifeszt ARVC esetén várható, tünetmentes mutáció hordozók, vagy borderline esetekben kialakulásuk valószínűsége alacsony. Egy közelmúltban publikált prospektív kohorsz vizsgálatban 116 desmosomális mutáció hordozó beteget (akiknél tartós kamrai ritmuszavar korábban nem jelentkezett) követtek átlagosan 8,5 éven át és vizsgálták az aritmiaesemények előfordulását. Mindössze 40 beteg esetében volt igazolható manifeszt ARVC, a többiek esetében borderline-betegség állt fenn, vagy fenotípusos eltérés nem volt kimutatható. A hirtelen szívhalál, kamrai tachycardia, indokolt ICD-működés kombinált végpontja a betegek $9 \%$-ában (10/116) jelentkezett, akik egy beteg kivételével mind a manifeszt ARVC-csoportba tartoztak. Az egyetlen beteg, akinél a hirtelen szívhalál manifeszt ARVC diagnózisa nélkül lépett fel egy 15 éves leány volt (igazolt DSG-mutációt hordozó) megelőzően negatív EKG-val, echokardiográfiás eredményekkel. De a posztmortem vizsgálat esetében kiterjedt bal kamrai hegesedést mutatott epikardiálisan, inferolaterálisan. Összességében az eredmények azt mutatják, hogy igazolt desmosomális mutáció esetén, de még manifeszt ARVC nélkül a „be- 
1. TÁBLÁZAT. Malignus kamrai ritmuszavarok, hirtelen szívhalál, vagy indokolt ICD-működés szempontjából prediktív faktorok ARVC-ben

Abortált HSZH vagy tartós KT
Súlyosan csökkent bal és/vagy jobbkamra-funkció (EF<35\%)
Syncope
NSVT
Mérs. csökkent bal és/vagy jobbkamra-funkció(EF: 35-40\%)
Férfinem
Többszörös patogén mutációk
Invertált T-hullámok száma 12 elvezetéses EKG-n
QRS-fragmentáció
QRS-amplitúdó csökkenése
Elektroanatómiai térképezés során a heg mérete

(EF: ejekciós frakció, HSZH: hirtelen szívhalál, KT: kamrai tachycardia, NSVT: nem tartós kamrai tachycardia)

tegség rejtett szakaszában" a hirtelen szívhalál-rizikó nagyon alacsony (5).

Manifeszt ARVC esetén számos olyan változó került leírásra, ami a HSZH, malignus kamrai ritmuszavar, vagy indokolt ICD-müködések független prediktorainak bizonyultak. A legfontosabb ezek közül a tartós kamrai tachycardia, kamrafibrilláció, de számos vizsgálatban az ismeretlen okból bekövetkező eszméletvesztés is. Emellett számos más rizikófaktor került leírásra, amelyek prediktívnek bizonyultak ARVC-ben a kamrai ritmuszavarok kialakulására: NSVT, bal és/vagy jobb kamrai diszfunkció, férfinem, többszörös patogén mutációk jelenléte, elektroanatómiai térképezés során a heg mérete, EKG-n az invertált T-hullámok száma a mellkasi és inferior elvezetésekben, QRS-fragmentáció és az alacsony QRS-amplitúdó (6). Ezen rizikófaktorok alapján 2015ben született meg egy nemzetközi konszenzus dokumentum, amely egyértelmü ajánlásokat is tartalmaz az ICD indikációját illetően (6). Ez a dokumentum a betegeket a HSZH rizikójuk alapján három kategóriába sorolja.

\section{Magas kockázat}

Ide tartoznak a HSZH-t túlélt, vagy tartós kamrai tachycardián átesett betegek mellett azok, akiknél súlyosan csökkent jobb- és/vagy balkamra-funkció áll fenn $<35 \%$ ejekciós frakcióval. Ezen esetekben az életet veszélyeztető éves kamrai aritmiakockázat 10\% fölötti, emiatt esetükben az ICD beültetése egyértelmúen javasolt (ajánlás erőssége: I.).

\section{Közepes kockázat}

Ide azok a betegek tartoznak, akik legalább egy kockázati tényezővel rendelkeznek, a fent felsoroltak közül. Esetükben az életet veszélyeztető kamrai ritmuszavarok kockázata 1-10\%. Ezen betegek közül ICD-implantáció Ila erősséggel javasolt major rizikófaktorok jelenléte esetén (syncope, NSVT, vagy mérsékelten csökkent jobb [EF: 35-40\%] és/vagy bal [EF: 36-45\%] kamra funkció esetén). Másfelől, egyéb rizikófaktorok jelenléte esetén a kockázat általában véve nem olyan magas, hogy rutinszerü ICD-implantációt igényeljen, emiatt ilyenkor csak válogatott esetekben jön szóba a készülék beültetése (Ilb).

\section{Alacsony kockázat}

Ide azok a betegek tartoznak, akiknél rizikófaktorok nincsenek jelen, illetve az egészséges patogén mutációhordozók. Esetükben az életet veszélyeztető kamrai aritmiakockázat $<1 \%$, emiatt ICD-implantáció nem javasolt (ajánlás erőssége: III.).

A szívelektrofiziológiai vizsgálattal kapcsolatban ellentmondásosak az eredmények, amelyet részben magyarázhat a vizsgálatok eltérő végpontja (életmentő vagy indokolt ICD-működés). A legnagyobb multicentrikus vizsgálatokban a programozott stimuláció prediktív értéke alacsony volt az életmentő ICD-terápiák előrejelzése szempontjából (6). Emiatt a jelenlegi konszenzusdokumentum Ilb erősséggel ajánlja a programozott sitmuláció elvégzését tünetmentes ARVC-s betegek rizikóstratifikációja céljából.

A szívizomsejtek közötti kapcsolódást biztosító desmosomális proteinek mutációja miatt ARVC-s betegekben minden olyan állapot, ami a kamrai falfeszülést fokozza, gyorsítja a betegség progresszióját, rontja a kimenetelt. Emiatt ezen betegek számára javasolt a verseny-, és kompetitiív sportok kerülése, csak alacsony intenzitású fizikai aktivitás engedélyezett. A tünetmentes, de patogén mutációhordozó családtagok esetében is a konszenzusdokumentum Ila erősséggel javasolja a kompetitív sportok kerülését, a betegség kialakulásának prevenciója céljából (6).

Amennyiben ICD implantációja válik szükségessé, a készülék típusát illetően a szubkután ICD mellett szól hogy alapvetően fiatal betegeknek kerül beültetésre, várhatóan hosszú ideig élnek a készülékkel és a transzvénás rendszerekkel kapcsolatos problémák egy része így kiküszöbölhető. Másfelöl komoly hátránya, hogy nem képes antitachycardia-ingerlésre (ATP), márpedig ARVC-ben a malignus kamrai ritmuszavarok jellemzően ATP-vel potenciálisan szüntethető monomorf kamrai tachycardiák.

Azon betegek esetében, akiknél az ICD-beültetésre kerül jellemzően magas az indokolt ICD-müködések aránya. A legnagyobb ilyen vizsgálatban, ahol 312 beteg utánkövetéséről vannak adatok már két év utánkövetésnél is a betegek több mint felében volt indokolt ICD-terápia megfigyelhető, 20\%-ukban pedig életveszélyes (kamrafibrilláció, kamrai flutter) kamrai ritmuszavar miatt (7). A ritmuszavarok előfordulási gyakoriságának csökkentésére adható antiaritmiás gyógyszerek közül ARVC-ben alapterápia a béta-blokkolók alkalmazása egyrészt csökkentik a falfeszülést, kedvező a hatásuk a szívelégtelenség lefolyására, másrészt bizonyítottan csökkentik az ARVC-ben jellemzően szimpatikotónia 
kapcsán előforduló kamrai ritmuszavarok gyakoriságát. Emiatt béta-blokkoló adása javasolt minden ARVC-s betegnek kamrai ritmuszavarok jelenlététől függetlenül (6). Mellettük a legtöbb adat amiodaron hatékonyságával kapcsolatban áll rendelkezésünkre, azonban alkalmazásánál mindig gondolni kell a potenciálisan súlyos mellékhatásprofilra, illetve, hogy jellemzően fiatal beteg esetében van szükség alkalmazására. Mint más etiológiák esetén a kamrai aritmiakontroll leghatékonyabb módja ARVC-ben is a katéterabláció, amelynek során a ritmuszavar kialakulását lehetővé tevő lassú vezetésű területek eliminációja történik meg radiofrekvenciás energia leadásával. A zsíros-kötőszövetes átalakulás lokalizációját figyelembe véve gyakran van szükség epikardiális megközelítésre és jellemzően ebből a megközelítésből nagyobb heges terület térképezhető, mint az endokardiális oldalról. A betegség progresszív természete miatt azonban már középtávon is magas (50$70 \%$ )-os kamrai aritmia rekurrenciával kell számolni (4).

\section{Következtetés}

ARVC-ben kamrai aritmiák megjelenésére manifeszt betegség esetén kell számítanunk. Közülük ICD-implantáció szekunder prevenciós célzattal, illetve profilaktikusan súlyosan csökkent bal és/vagy jobbkamra-funkció esetén indokolt (I. osztályú ajánlás), de szintén gondolni kell rá major rizikófaktorok megléte esetén.
Irodalom

1. Corrado D, Link MS, Calkins H. Arrhythmogenic right ventricular cardiomyopathy. N Engl J Med 2017; 376: 61-72. doi: 10.1056/ NEJMra1509267.

2. Marcus FI, McKenna WJ, Sherrill D, Basso C, Bauce B, Bluemke BA. Diagnosis of arrhythmogenic right ventricular cardiomyopathy/dysplasia: proposed modification of the task force criteria. Circulation 2010; 121(13): 1533-41. doi: 10.1161/CIRCULATIONA HA.108.840827

3. Basso C, Pilichou K, Bauce B, Corrado D, Thiene G. Diagnostic Criteria, Genetics, and Molecular Basis of Arrhythmogenic Cardiomyopathy. Heart Fail Clin 2018; 14(2): 201-213. doi: 10.1016/j. hfc. 2018.01.002

4. Gandjbakhch E, Redheuil A, Pousset F, Charron P, Frank R. Clincal diagnosis, imaging, and genetics of arrhythmogenic right ventricular cardiomyopathy/dysplasia. J Am Coll Cardiol 2018; 72: 784 804. doi: 10.1016/j.jacc.2018.05.065

5. Zorzi A, Rigato I, Pilichou K, Marra MP, Migliore F, Mazzotti E, et al. Phenotypic expression is a prerequisite for malignant arrhythmic events and sudden cardiac death in arrhythmogenic right ventricular cardiomyopathy. Europace 2016; 18: 1086-1094. doi: 10.1093/ europace/euv205

6. Corrado D, Wichter T, Link MS, Hauer RNW, Marchlinski FE, Anastasakis A, et al. Treatment of Arrhythmogenic Right Ventricular Cardiomyopathy/Dysplasia An International Task Force Consensus Statement. Circulation 2015; 132: 441-453. doi: 10.1161/CIRCULATIONAHA.115.017944

7. Orgeron GM, James CA, Riele AT, Tichnell C, Murray B Bhonsale A, et al. Implantable Cardioverter-Defibrillator Therapy in Arrhythmogenic Right Ventricular Dysplasia/Cardiomyopathy: Predictors of Appropriate Therapy, Outcomes, and Complications. Am Heart Assoc 2017; 6: e006242. doi: 10.1161/ JAHA.117.006242



International and World Congresses
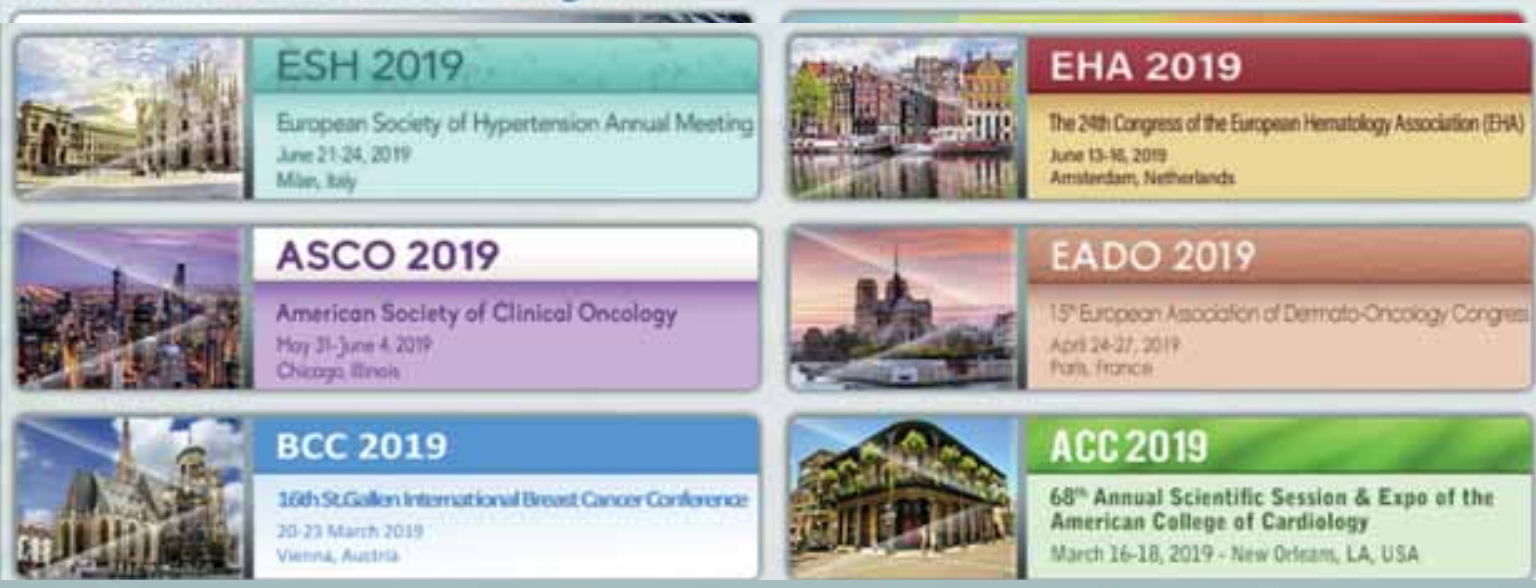

Látogassa meg a congressreport.eu portâlunkat! 